\title{
The ZmRCP-1 promoter of maize provides root tip specific expression of transgenes in plantain
}

\author{
Stephen O. Onyango ${ }^{1,2}$, Hugh Roderick ${ }^{3}$, Jaindra N. Tripathi ${ }^{1}$, Richard Collins ${ }^{3}$, Howard J. Atkinson ${ }^{3}$, \\ Richard O. Oduor ${ }^{2}$ and Leena Tripathi ${ }^{*}$
}

\begin{abstract}
Background: Bananas and plantains (Musa spp.) provide $25 \%$ of the food energy requirements for more than 100 million people in Africa. Plant parasitic nematodes cause severe losses to the crop due to lack of control options. The sterile nature of Musa spp. hampers conventional breeding but makes the crop suitable for genetic engineering. A constitutively expressed synthetic peptide in transgenic plantain has provided resistance against nematodes. Previous work with the peptide in potato plants indicates that targeting expression to the root tip improves the efficacy of the defence mechanism. However, a promoter that will provide root tip specific expression of transgenes in a monocot plant, such as plantain, is not currently available. Here, we report the cloning and evaluation of the maize root capspecific protein-1 (ZmRCP-1) promoter for root tip targeted expression of transgenes that provide a defence against plant parasitic nematodes in transgenic plantain.
\end{abstract}

Results: Our findings indicate that the maize ZmRCP-1 promoter delivers expression of $\beta$-glucuronidase (gusA) gene in roots but not in leaves of transgenic plantains. In mature old roots, expression of gusA gene driven by ZmRCP-1 becomes limited to the root cap. Invasion by the nematode Radopholus similis does not modify Root Cap-specific Protein-1 promoter activity.

Conclusions: Root cap-specific protein-1 promoter from maize can provide targeted expression of transgene for nematode resistance in transgenic plantain.

Keywords: Plantain, Root specific promoter, Nematode invasion, $\beta$-glucuronidase, Transgenic defence

\section{Background}

Bananas and plantains (Musa spp.) are ranked 8th in the global harvest of staple crops $[1,2]$ providing $25 \%$ of the food energy requirements of over 100 million Africans [3]. Several species of plant parasitic nematodes including Radopholus similis cause severe yield losses to these crops [4-6] and there are very few control options available to farmers in Africa. Plantains are not readily improved by conventional plant breeding because of their sterile and triploid nature. This characteristic, however, eliminates the risk of transgene flow and so enhances the

\footnotetext{
*Correspondence: L.Tripathi@cgiar.org

${ }^{1}$ International Institute of Tropical Agriculture (IITA), P.O. Box 7878,

Kampala, Uganda

Full list of author information is available at the end of the article
}

biosafety of genetic engineering. Consequently, a transgenic approach that can address the need to control the pests and diseases that hamper production of the crop is favourable [7].

One promising approach for nematode control involves transgenic expression of a non-lethal synthetic disulphide-constrained 7-mer peptide with the amino acid sequence CTTMHPRLC [8]. It is taken up by nematode chemoreceptive neurons and subsequently disrupts coordinated responses to chemoreception and limits root invasion by the pathogen $[9,10]$. It confers resistance in the field to a cyst nematode on potato [11] and to $R$. similis on plantain in a glasshouse [8] and field [12], when expressed constitutively with a cellular export signal. It is 
rapidly degraded in soil and is without adverse effects on non-targeted soil nematodes $[8,11]$.

Targeted expression for defence such as the synthetic peptide requires a promoter that is active at the site of invasion by the nematodes. In potato, the Arabidopsis root cap specific MDK4-20 promoter driving a synthetic peptide conferred a higher level of resistance to Globodera pallida than the constitutive CaMV35S promoter [13]. To date, only constitutive heterologous promoters from maize ubiquitin 1 , the rice actin 1 [14] or a CaMV35S promoter enhanced for monocot expression $[15,16]$ have been used for the production of transgenic banana plants. Several promoters are known to be actively driving expression of transgene in the roots of rice including rolC [17], RCg2 [18], Tub-1 [19] and PHT1 [20]. Though rolC and RCg2 also drove gusA expression in leaf sheaths, gus $A$ expression from the Tub-1 promoter rapidly declined as the plants aged while the expression from the PHT1 promoter is dependent on the level of phosphate in the growing medium. None of the studied promoters provide root tip specific expression required for anti-nematode defences.

The delivering of gene expression to tissues invaded by nematodes by a promoter that drives a defence must also continue to express throughout the infection process. The gusA and $g f p$ expression from the CaMV35S promoter has been shown to be progressively down regulated at the infection sites of Meloidogyne incognita and cyst nematodes in Arabidopsis thaliana roots [21, 22]. GUS activity from the CaMV35S promoter is also limited following Heterodera schachtii infection in the roots of $A$. thaliana [23]. However, MDK4-20 promoter of $A$. thaliana directs effective root-specific transgenic expression of the secreted nematode-repellent peptide in $A$. thaliana and Solanum tuberosum [13]. The Zea mays Root Cap-specific Protein-1 (ZmRCP-1) is a homologue of the Arabidopsis MDK4-20 gene and is active in lateral root cap cells in maize [24]. In this study, we demonstrate that the ZmRCP-1 promoter provides a root tip specific activity suitable to deliver the anti-nematode defences in a monocot crop plant.

\section{Results}

\section{Preparation and validation of plasmid constructs}

The construct pBI-RCP-1:GUS was prepared by cloning the $\mathrm{ZmRCP}-1$ promoter and inserting the promoter fragment into the HindIII and BamHI sites of the binary vector pBI121 immediately $5^{\prime}$ to the $\beta$-glucuronidase (gusA) gene (Fig. 1a). The pBI121 plasmid containing the gusA gene under regulation of CaMV35S promoter was used as the constitutive expression construct (Fig. 1b). These constructs were confirmed by sequencing and then transferred to Agrobacterium tumefaciens strain EHA105.
The plasmid constructs were isolated from colonies of transformed A. tumefaciens and verified by PCR analysis using the promoter specific primers. The amplicon of $2 \mathrm{kbp}$ was obtained for pBI-RCP-1:GUS amplifying the ZmRCP-1 promoter and fragment of $835 \mathrm{bp}$ amplifying the CaMV35S promoter was observed in pBI121 plasmid construct (Fig. 1c).

\section{Generation and validation of transgenic plantains}

The Agrobacterium-infected embryogenic cells multiplied and regenerated on kanamycin selective medium whereas the control untransformed cells turned black (Fig. 2a-d). In total, 20 lines of RCP-1:GUS and 15 lines of CaMV35S:GUS of plantain cv. 'Gonja manjaya' were generated from one Agrobacterium-mediated transformation experiment using cell suspension. The regenerated transgenic shoots were proliferated and transferred to rooting medium. All the shoots developed roots within 2-3 weeks (Fig. 2e). The rooted plantlets were transferred to the soil in pots in contained glasshouse (Fig. 2f). The lines were confirmed by PCR analysis to contain the gusA gene, including those used for further studies (Fig. 3).

A histochemical GUS assay performed on the young tissue culture plants from the laboratory revealed expression of gusA in all roots of RCP-1:GUS lines and CaMV35S:GUS lines. The CaMV35S:GUS lines had uniform blue staining in leaves (Fig. 4a) and roots (Fig. 4b) whereas RCP-1:GUS lines stained intensely blue at the root tips and showed less intensity of blue coloration in the upper parts of the root (Fig. 4d). No staining was observed in the leaves of RCP-1:GUS lines (Fig. 4e). Similar results were observed for all of the 20 lines of RCP1:GUS and the 15 lines of CaMV35S:GUS.

\section{Histochemical GUS analysis in infected roots of plantain}

The GUS activity in plants grown in soil with or without nematode challenge was assessed. The pot grown CaMV35S:GUS lines showed uniform expression of gusA in roots at 28 days post infection (dpi) (Fig. 5a) similar to in vitro plants of the same line (Fig. 4). The same was true for the pot grown RCP1:GUS lines, which showed gusA expression only in the root tips at $28 \mathrm{dpi}$ with $R$. similis (Fig. 5b) similar to in vitro plants of the same line (Fig. 4). Infection with $R$. similis had no effect upon the gusA expression pattern of RCP-1:GUS lines (Fig. 5b) when compared to non-infected plants (Fig. 5c).

\section{Nematode root invasion and establishment}

Two experiments, using two different cultivars of banana, were carried out to study root invasion by nematodes. In a preliminary experiment, which was done to establish the protocol with banana cv. 'Cavendish', $100 R$. similis were inoculated close to root tips of 16 non-transgenic 


\section{a}
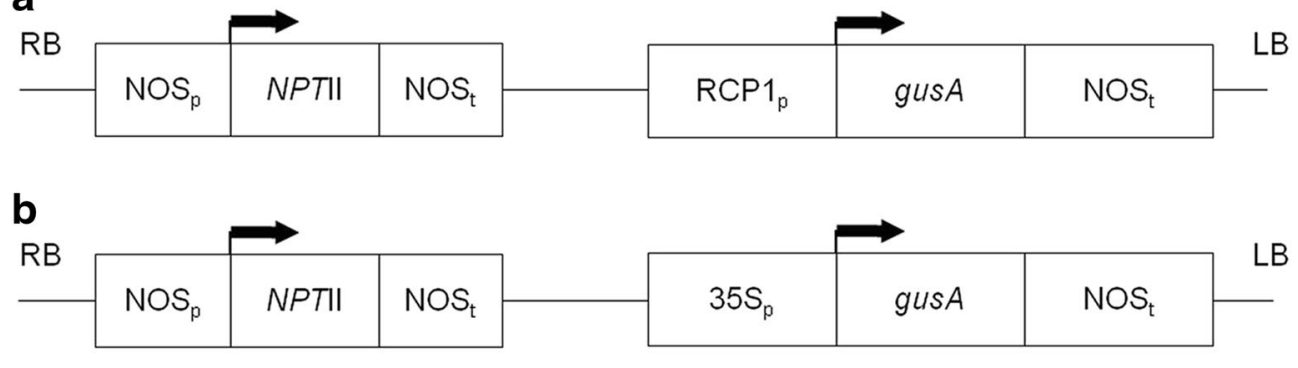

C
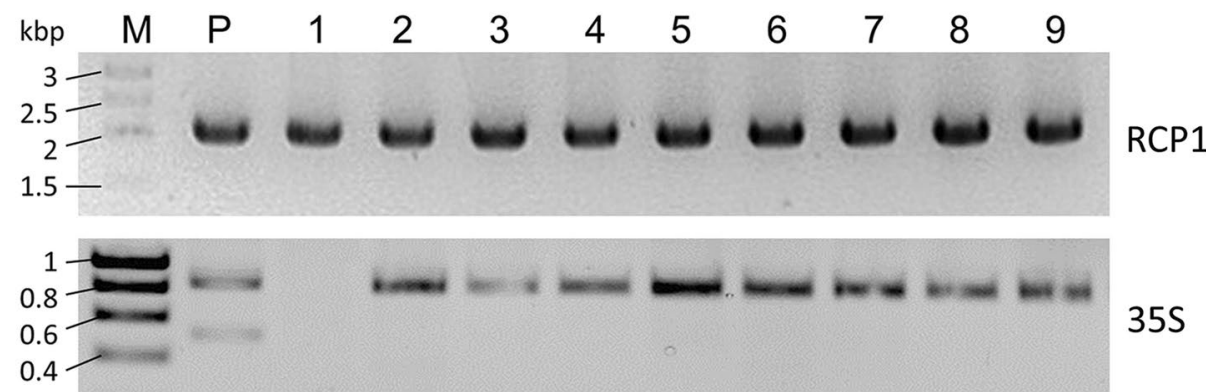

$35 \mathrm{~S}$

Fig. 1 Schematic presentation and validation of plasmid constructs. a pBI-RCP-1:GUS- the maize Root Cap-specific Protein-1 promoter (RCP1 p $^{2}$ drives expression of the $\beta$-glucuronidase (gusA) gene. b pBI121- the cauliflower mosaic virus CaMV35S promoter ( $35 S_{p}$ ) drives expression of the gus A gene. For both constructs the nopaline synthase promoter (NOSp) was used to drive expression of the neomycin phosphotransferase II (nptll) gene and the nopaline synthase terminator (NOSt) was used as the 3' poly-A signal for both the selectable marker nptll and gusA genes. Left (LB) and right (RB) borders of the T-DNA and translation start sites with the direction of transcription are also indicated. $\mathbf{c}$ Polymerase chain reaction screen of Agrobacterium tumefaciens strain EHA105 colonies (1-9) transformed with pBI-RCP-1:GUS or pBI121. RCP1 primers amplify a 2 kbp fragment and the $35 \mathrm{~S}$ primers amplify an $835 \mathrm{bp}$ fragment. M—-molecular size marker with sizes of bands indicated; $\mathrm{P}$-positive control using the plasmid used for transformation

banana plantlets of cv. 'Cavendish'; all nematodes were within $15 \mathrm{~cm}$ of the root tip. The distribution of the nematodes was such that $50 \%$ of them $( \pm 95 \%$ confidence limits) were present within $5.92 \pm 0.77 \mathrm{~cm}$ of the root tips for the 'Cavendish' plants. This was followed by an experiment with the transgenic cv. 'Gonja manjaya' plants developed in this study along with non-transgenic controls. A mixed population of $R$. similis, Helicotylenchus multicinctus and $M$. incognita was used for inoculation of 'Gonja manjaya.' The population of $R$. similis was highest near the root tips of this plantain and declined distally. At $7 \mathrm{dpi}, 83 \%$ of $R$. similis were present in the first $8 \mathrm{~cm}$ distal to the root tip but a few nematodes were also present at 12 and $24 \mathrm{~cm}$. However, at $14 \mathrm{dpi}$ all $R$. similis were within $8 \mathrm{~cm}$ of the root tip (Fig. 6). In total, only eight $M$. incognita and eight $H$. multicinctus were recovered from the roots and all were within $6-12 \mathrm{~cm}$ of the root tip (Fig. 6).

\section{Discussion}

\section{Analysis of GUS activity in transgenic plantains}

This work establishes the potential of ZmRCP-1 promoter isolated from maize for delivering transgenic traits when activity is only required at the root tips of transgenic plantain. As expected, the CaMV35S promoter provided intense gus A expression along the root and in leaf tissues (Figs. 4, 5). Such constitutive expression is an undesirable trait in commercial transgenic plants when only particular tissues need to express a transgene to provide the trait of interest such as nematode resistance. ZmRCP-1 has provided an expression pattern that is limited to the root tips of both tissue culture and soil grown plants up to 28 dpi (Fig. 5). Further work is required to establish the root expression pattern across the whole crop cycle under field conditions. There is a need to confirm the expression in younger root tissues close to the tips persists in mature plants and that the nematodes remain predominately in this region. Additionally, protection of roots in younger banana plants is important to favour crop establishment.

In maize, $\mathrm{ZmRCP}-1$ expression is restricted to the lateral root cap cells and does not extend more than about $0.3 \mathrm{~mm}$ behind the root tip [24]. In contrast, this promoter delivered expression of gus A gene in transgenic plantain that extended throughout young roots and to $0.5 \mathrm{~cm}$ from the tip in mature roots (Fig. 6). A similar difference in pattern of expression between plants has been reported for MDK4-20 a homolog of ZmRCP-1 isolated from A. thaliana [13]. The MDK4-20 promoter directed 


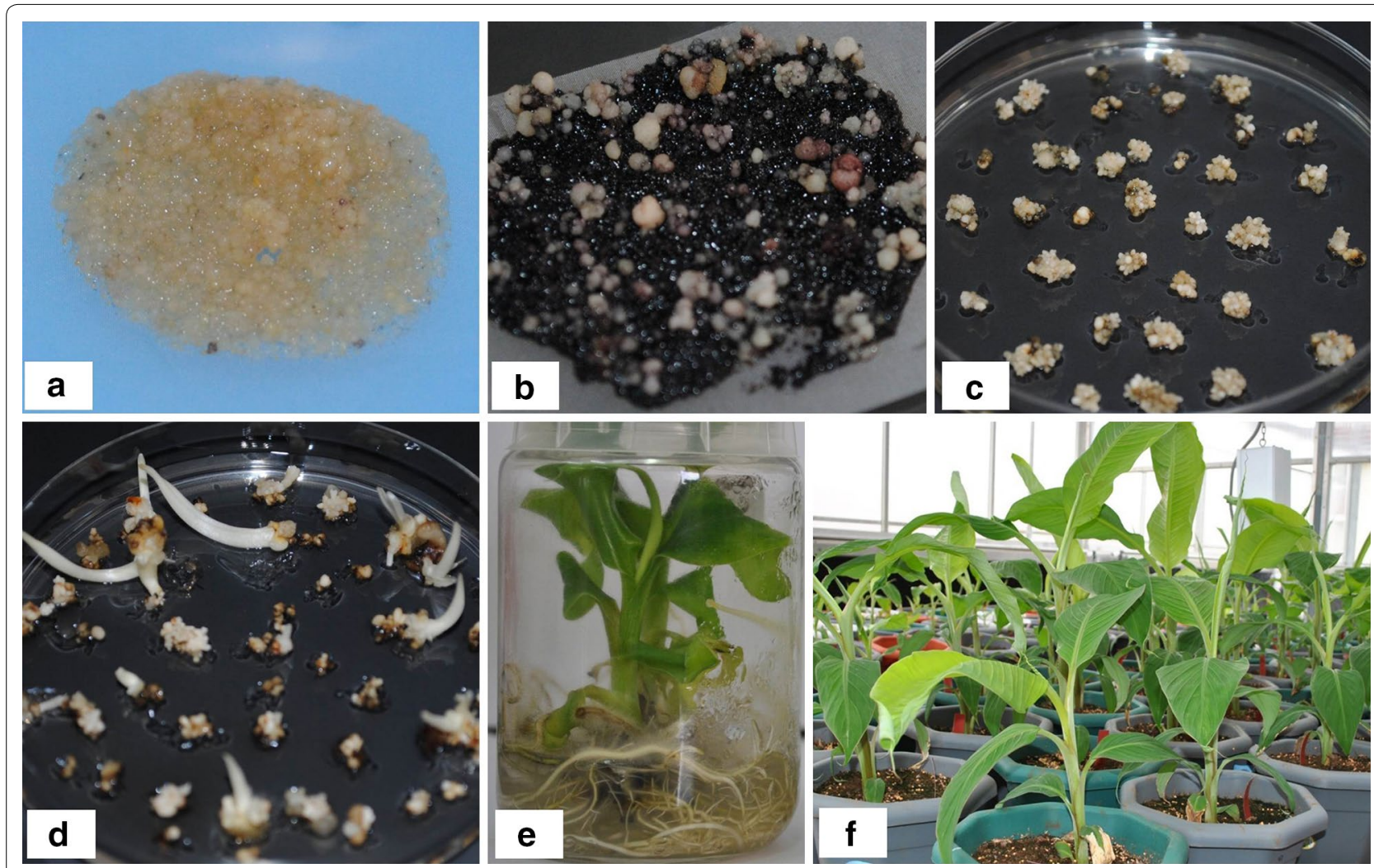

Fig. 2 Regeneration of transgenic lines of plantain cv. 'Gonja manjaya'. a Embryogenic cells infected with EHA105 Agrobacterium tumefaciens cells harbouring pBI-RCP-1:GUS or pBI121 construct. b Proliferation of Agrobacterium-infected cells on kanamycin selective medium. c Embryos developing on kanamycin selective medium. d Germinating transgenic seedlings from mature embryos on selective medium. e Transgenic plantlets on rooting medium. $\mathbf{f}$ Transgenic plants in pots in the glasshouse

the expression of gus A gene specifically to peripheral cells of root tip and lateral root cap cells of $A$. thaliana $[13,24]$. Its activity in potato was also in outer cells of the root tip but it extended further towards the zone of elongation. This less restricted pattern of expression in potato delivered a higher level of repellent peptide defence to cyst nematodes in potato than in A. thaliana where the pattern of expression was more limited [13].

In this study, vegetatively micro-propagated transgenic plantains of cv. 'Gonja manjaya' for several cycles were used to investigate the gusA expression pattern under the control of ZmRCP-1 promoter. Similar study has been conducted with vegetatively micro-propagated $S$. tuberosum to establish the root cap specific expression of gusA under AtMDK4-20 promoter [13]. Transgenic plants of 'Gonja manjaya' expressing a cystatin and a synthetic peptide to provide single and dual resistance against soil nematodes have also been studied under screen house and field conditions $[8,12]$. Field trial of Xanthomonas wilt disease-resistant bananas have been carried out using vegetatively propagated bananas [25]. In other studies, vegetatively micro-propagated plants have been used to confirm the role of $A$. thaliana NHL1 and NHL8 genes in the Soybean defence mechanism against Heterodera glycines [26] and in post-transcriptional hairpin RNA-mediated gene silencing of vital fungal genes to confer resistance against Fusarium wilt in banana [27].

\section{The GUS activity in nematode infected roots}

There were no significant differences between the population means of R. similis per $100 \mathrm{~g}$ root for the transgenic plants of ZmRCP-1 lines and CaMV35S lines and non-transgenic control plants. The gus A gene expression is known not to affect nematode establishment in plants and this has been evident in previous studies of nematode invasion $[19,21]$. A decline in ZmRCP-1 promoter activity with root age is also evident in this study (Figs. 4, 5). The GUS activity becomes root cap specific and the promoter activity is restricted within $5 \mathrm{~mm}$ from the tip at $28 \mathrm{dpi}$ (Fig. 5). In younger roots, GUS activity was high at the root tip but also extended further up the root end (Fig. 4). It is observable that there was a variation in the intensity of GUS expression between the roots of young tissue culture plants and those of older plants 

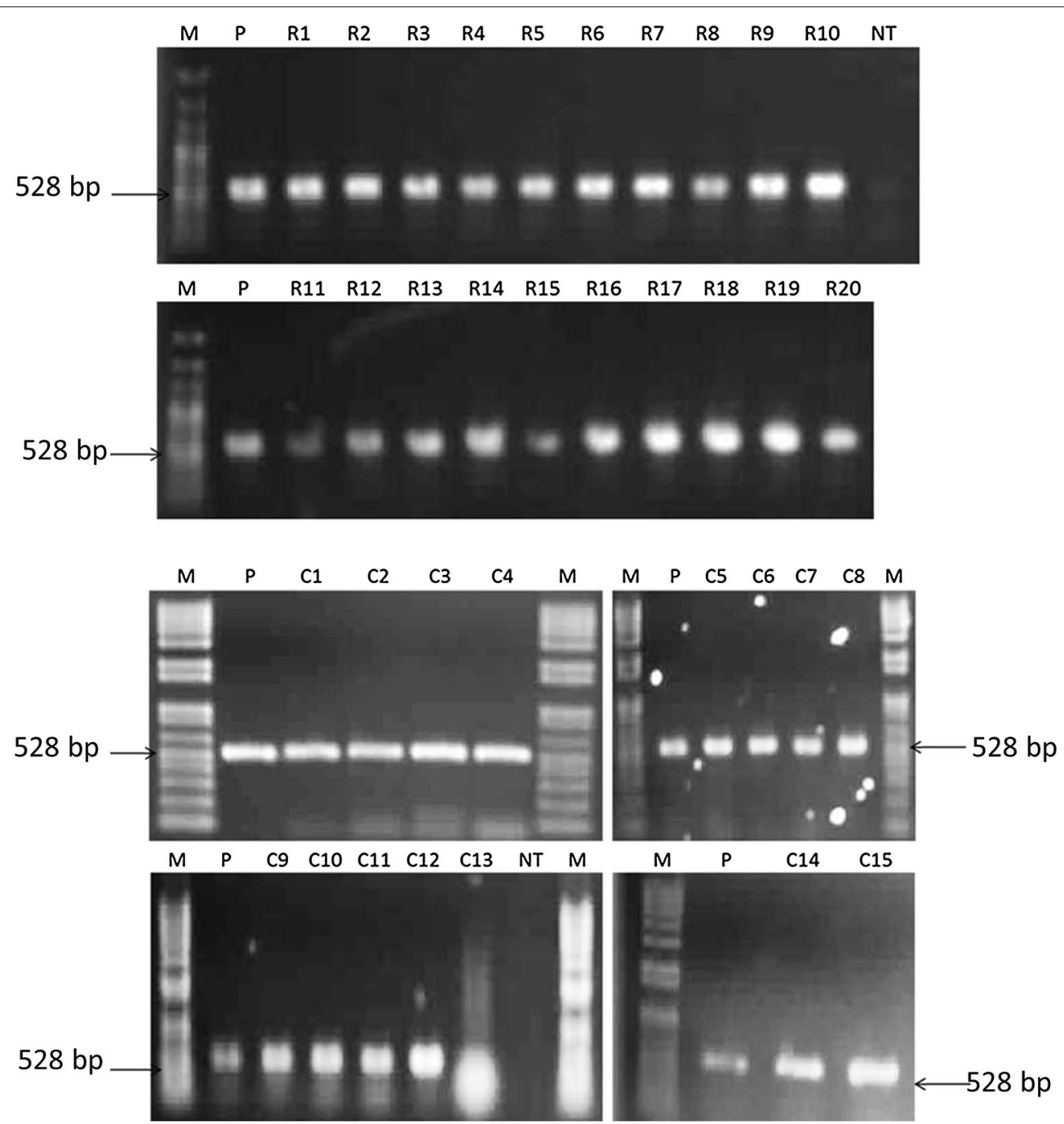

Fig. 3 PCR analysis of transgenic plantain lines. Positive transgenic lines screened by PCR for a 528 bp region of the gusA gene. Amplification from the pBI121 plasmid was used as a positive control $(P)$ and amplification from the genomic DNA of a non-transformed plantain was used as a negative control (NT). Twenty RCP-1:GUS lines (R) and 15 35S:GUS lines (C) were positive. 100 bp plus DNA ladder (M) used to assess size of amplified bands

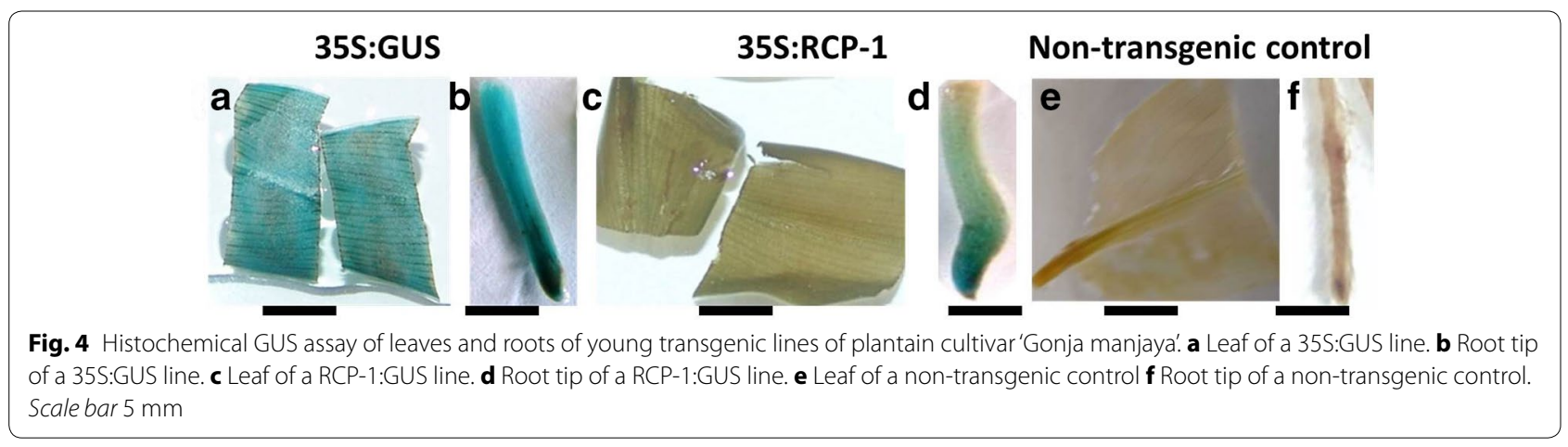




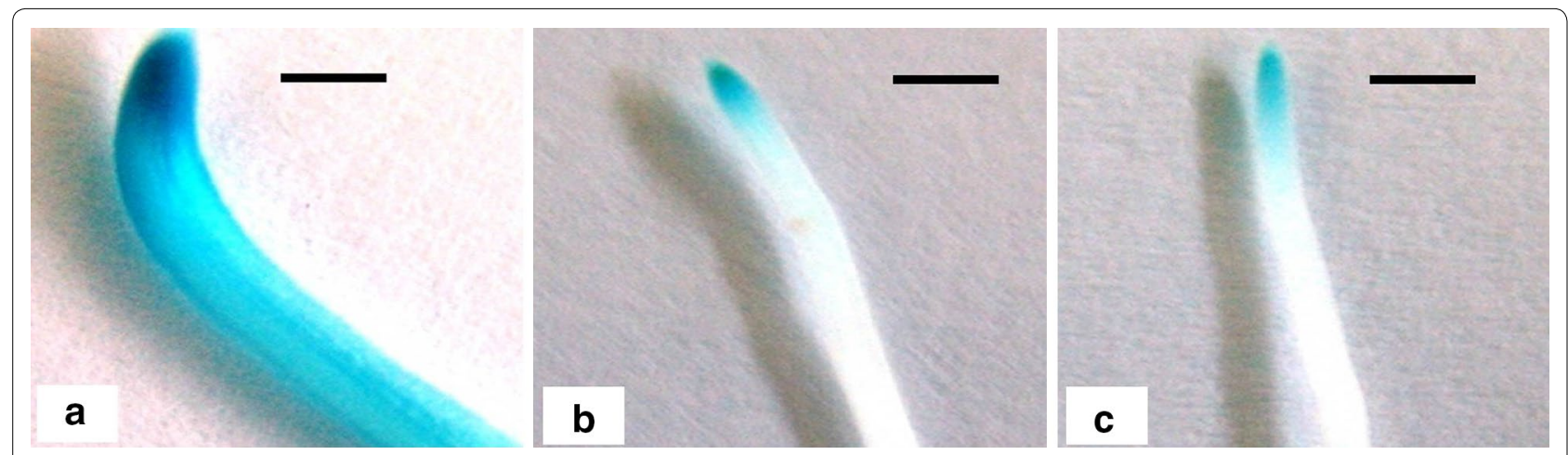

Fig. 5 Histochemical GUS assay performed on nematode infected roots of transgenic plantains at 28 days post infection. a GUS stained nematode infected root of 35S:GUS line. b GUS stained nematode infected root of RCP-1:GUS line. c GUS stained uninfected root of RCP-1:GUS line Scale bar $5 \mathrm{~mm}$

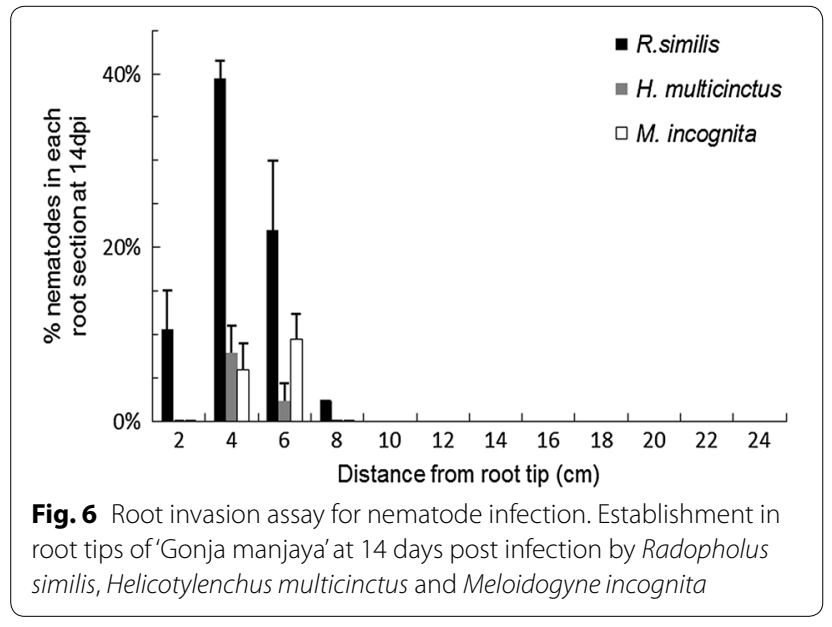

at 28 dpi (Figs. 4, 5). A decline in promoter activity has been reported previously for other root active promoters. For instance it occurs partially for that from ubiquitin-1 (Ubi-1) and fully for the promoter of tubulin-1 (Tub-1) over 10 weeks in rice roots [19]. On rice, Pratylenchus zeae feeds similarly to $R$. similis on Musa spp. Similar to this work, nematodes did not modify Ubi-1 or Tub-1 promoter activity in rice [19].

The particular advantage of expressing anti-nematode defences in root cap cells is that they are responsible for much of root exudation. They also remain active for a period of up to a few days after detachment from the root [13]. This ensures delivery of the defence to the nematode in the rhizosphere before root invasion can occur. The efficacy of a root-cap active promoter in delivering nematode control also depends on other factors. One is the rate of root border cell production. Two Musa acuminata cultivars produce a relatively high number of these cells [28] and many more than Solanaceae [13, 29]. Border cell production is conserved at the plant family level but regulated by endogenous and environmental signals [29].

\section{Nematodes invasion and establishment in the roots}

This work established that $R$. similis preferentially feed in the first few centimeters of both plantain cv. 'Gonja manjaya' (Fig. 6) and dessert banana cv. 'Cavendish' roots. While expression from the ZmRCP-1 is present in the more proximal root regions that harboured nematodes, previous studies have reported a preferential invasion and establishment of nematodes close to the root tip. M. incognita [30] and $R$. similis [31,32] preferentially invade the roots near the root apex. Expression at the root apex and in root border cells, as is the case here, therefore delivers the peptide to the locale of nematode invasion. Constitutive expression of the peptide-mediated nematode defence is not required in parts of the plant where these parasites do not occur. Restricting expression to roots avoids unwanted exposure to the transgene of non-target organisms associated with aerial tissues. It also ensures that the plant is not burdened with miss-targeted production of the defence.

\section{Conclusion}

Targeted expression of a transgenic defence designed to disrupt nematode invasion and establishment requires a root tip specific promoter. Such promoters exist for dicot plants; for instance, phytase has been secreted into the rhizosphere of potato plants using the promoter of the tomato LeExt1.1 gene that directs expression in trichoblasts [33]. However, such promoters are not available for monocot plants. Our study demonstrated that ZmRCP-1 promoter directs the expression of gusA reporter gene to root cap in transgenic plantain. ZmRCP-1 promoter has potential to provide targeted expression of transgene for nematode resistance in transgenic plantain, potentially contributing to the biosafety of nematode resistant plantains if it delivers effective peptide-mediated resistance 
to banana nematodes throughout the cropping cycle. We intend to develop transgenic plantains expressing a repellent peptide under the control of ZmRCP-1 promoter.

\section{Methods}

\section{Plasmid constructs}

For the root cap specific construct, the ZmRCP-1 promoter was cloned from a Corn Lambda Genomic Library (Stratagene, La Jolla, CA, USA) using forward (5'-GT TACTAAGC TTCC TATGTCAATTAAGG GAGTTGATG-3') and reverse (5'-GTTACTGGATCCAGCTCATACTGCTTCTGTGACTGT-3') primers that amplified $2 \mathrm{kbp}$ immediately $5^{\prime}$ to the RCP-1 open reading frame [24] and introduced $5^{\prime}$ HindIII and $3^{\prime}$ BamHI restriction sites. Amplification was performed using Phusion High-Fidelity DNA Polymerase (NEB, MA, USA) using cycling conditions of $30 \mathrm{~s} @ 98{ }^{\circ} \mathrm{C}$ followed by 30 cycles of $10 \mathrm{~s} @ 98{ }^{\circ} \mathrm{C}, 15 \mathrm{~s} @ 60^{\circ} \mathrm{C}$ and $30 \mathrm{~s} @$ $72{ }^{\circ} \mathrm{C}$ with a final extension step at $72{ }^{\circ} \mathrm{C}$ for $10 \mathrm{~min}$. The ZmRCP-1 promoter fragment was cloned into the HindIII and BamHI sites of the binary vector pBI121 [34] immediately $5^{\prime}$ to the $\beta$-glucuronidase (gusA) gene to generate construct pBI-RCP-1:GUS (Fig. 1a) using standard molecular cloning techniques [35]. For the constitutive expression construct, pBI121 plasmid that already contained the gusA gene under regulation of CaMV35S promoter [34] was used (Fig. 1b). Both constructs were confirmed by sequencing before transforming into $A$. tumefaciens strain EHA105 [36] by electroporation. Constructs were verified by PCR analysis using the same primers used for cloning the ZmRCP-1 promoter. For pBI121, forward primer (5'-ACATCTAGAATGGTG GAGCACGACAC-3') and reverse primer (5'-ACAG GATCCTCGAGAGAGATAGATTTG-3') were used that amplify the 835 bp of CaMV5S promoter (Fig. 1). Amplification conditions were the same as for cloning.

\section{Plant material, transformation and regeneration}

Embryogenic cell suspension of plantain cv. 'Gonja manjaya' (Musa spp. AAB) was transformed as described previously [16]. The Agrobacterium-infected embryogenic cell suspensions were regenerated on selective medium supplemented with cefotaxime $\left(300 \mathrm{mg} \mathrm{L}^{-1}\right)$ and kanamycin (100 $\mathrm{mg} \mathrm{L}^{-1}$ ) with transfer every 2 weeks to fresh medium of the same type. The regenerated transgenic shoots were maintained and multiplied on proliferation medium consisting of Murashige and Skoog (MS) medium [37] supplemented with $5 \mathrm{mg} \mathrm{L}^{-1}$ benzylaminopurine (BAP), at $28{ }^{\circ} \mathrm{C}$ for a $16 / 8 \mathrm{~h}$ light/dark photoperiod under fluorescent tube lights. Regenerated putative transgenic shoots were transferred to rooting medium (MS medium supplemented with $1 \mathrm{mg} \mathrm{L}^{-1}$ indole-3-butyric acid [IBA]). Rooted plantlets were transferred to sterile soil in pots and maintained in a contained glasshouse. Regenerated putative transgenic shoots were regularly micro-propagated and clonally multiplied to obtain sufficient plantlets of each line for nematode challenge in glasshouse and maintenance of the line in vitro.

The transformation experiments were performed at biosafety level II research facility of National Agricultural Research Laboratories following the national biosafety guidelines.

\section{Genomic DNA isolation and PCR analysis of transgenic lines}

The plant genomic DNA was extracted from the regenerated putative transgenic plants using a DNeasy kit (Qiagen, Hilden, Germany) from leaf tissue of in vitro plants ground using liquid nitrogen. DNA quality and concentration was determined by NanoDrop 2000c (Thermo Scientific, Wilmington, USA). PCR analysis was performed using gusA gene specific primers to confirm the presence or absence of the transgene in the plant genome. The forward (5'-TTTAACTATGCCGGAATCCATCGC-3') and reverse (5'-CCAGTCGAGCATCTCTTCAGCGTA-3') primers amplify a 528 bp region of the gusA gene. PCR amplification was carried out in a total volume of $20 \mu \mathrm{L}$ containing $4 \mu \mathrm{L}$ of $200 \mathrm{ng} \mu \mathrm{L}^{-1}$ genomic DNA, $0.5 \mu \mathrm{L}$ of each $0.2 \mu \mathrm{M}$ primer and $10 \mu \mathrm{L}$ of GoTaq Green Master Mix (Promega, Madison, USA). Thermocycling began with denaturation at $94{ }^{\circ} \mathrm{C}$ for $5 \mathrm{~min}$, followed by 35 cycles of $94{ }^{\circ} \mathrm{C}$ for $50 \mathrm{~s}, 55^{\circ} \mathrm{C}$ for $40 \mathrm{~s}$ and $72{ }^{\circ} \mathrm{C}$ for $50 \mathrm{~s}$, and a final extension of $72{ }^{\circ} \mathrm{C}$ for $10 \mathrm{~min}$.

\section{Histochemical detection of gusA expression in transgenic plantain}

Histochemical detection of the gusA gene was carried out according to the modified protocol of Jefferson [38] as described in Tripathi et al. [16]. Roots and leaf material were washed in $70 \%$ ethanol for $2 \mathrm{~min}$ and fixed in $0.3 \% \mathrm{v} / \mathrm{v}$ formaldehyde, $10 \mathrm{mM}$ MES, $\mathrm{pH}$ 5.6, $0.3 \mathrm{M}$ mannitol for $45 \mathrm{~min}$ at room temperature followed by three washes in $50 \mathrm{mM}$ sodium phosphate, $\mathrm{pH}$ 7.0.

The fixed material was vacuum-infiltrated in substrate solution (1 mM X-gluc, $50 \mathrm{mM}$ sodium-phosphate, $\mathrm{pH}$ 7.0, $5 \mathrm{mM}$ potassium ferricyanide, $5 \mathrm{mM}$ potassium ferrocyanide, $10 \mathrm{mM}$ EDTA and $50 \mathrm{mM}$ ascorbic acid) for $4 \mathrm{~min}$ and then incubated at $37^{\circ} \mathrm{C}$ for $48 \mathrm{~h}$. The chlorophyll of the leaf material was then removed by immersing in $1 \% \mathrm{NaOCl}$ solution for $3 \mathrm{~h}$ and subsequently dehydrated in sequential $30 \mathrm{~min}$ incubations in 50, 70 and $95 \%$ ethanol. Staining was imaged by DSC-F828 camera (Sony, New York, NY, USA).

\section{Nematode challenge}

The nematode challenge trial was carried out in a contained screen house authorised for use with transgenic 
plants at the National Agricultural Research Laboratories (NARL) at Kawanda, Uganda. Forty two transgenic plants and six non-transgenic plants for the nematode challenge trial were set up in a randomized design within the screen house. Three plants each of five lines of ZmRCP-1, two lines of CaMV35S and non-transgenic control plants (24 plants in total) were challenged with nematodes in a bioassay. The potted plants were grown for 8 weeks before inoculation with 1000 juveniles of $R$. similis per plant. The nematodes were watered onto GF/A filter paper and placed onto exposed roots. Three plants of each transgenic and the non-transformed lines were left uninfected as controls. The trial continued for a further 4 weeks in the screen house at ambient temperatures with daily watering. The height, girth and numbers of functional leaves were recorded at 2 week intervals and were used to calculate the total leaf area (TLA), TLA $=\mathrm{n}(0.411 \mathrm{G}+0.381 \mathrm{H}-0.404)$ where $\mathrm{n}$ is the number of functional leaves more than $50 \%$ green and fully attached to the pseudostem, G is girth $(\mathrm{cm})$ at the base of the pseudostem and $\mathrm{H}$ is the plant height $(\mathrm{cm})$ measured from the base to the axil of the topmost pair of fully expanded leaves [39]. Root samples, including root tip, were collected from each plant at infection and at 4 weeks for histochemical detection of gus A expression. At the end of the trial, the root tissue fresh weight was recorded before the roots were cut into $1 \mathrm{~cm}$ pieces. Root samples were placed in polypropylene bags and submerged in $10 \mathrm{ml}$ of $1 \% \mathrm{H}_{2} \mathrm{O}_{2}$ solution [40]. Nematodes were collected and counted using a stereo-microscope after 7 days of incubation at room temperature in the dark.

\section{Analysis of roots invasion by nematodes}

The analysis was done to determine the distribution of nematodes population at various root sections from the start of the infection period. An initial experiment was carried out using 16 plants of banana cv. 'Cavendish' that were infected with $R$. similis for 28 days to determine the distribution of nematodes along the length of roots in which the nematodes occurred. The subsequent experiment used mixed population of 1000 nematodes containing equal numbers of $R$. similis, $H$. multicinctus and $M$. incognita to infect roots of 10 non-transgenic control plants of cv. 'Gonja manjaya'. At 7 days post infection (dpi), roots of five of the plants were collected cut into $2 \mathrm{~cm}$ sections and pooled into $2 \mathrm{~cm}$ groups from the root tip. The nematodes that emerged from the roots were counted in $200 \mu \mathrm{l}$ aliquots using a stereo-microscope. The procedure was repeated for the remaining five plants at $14 \mathrm{dpi}$.

\section{Statistical analysis}

All data were analyzed using SPSS v20 (IBM Corporation Armonk, New York, USA; http://www-01.ibm.com/ software/analytics/spss). The choice of analysis used for data was informed by both the help files of the package and a standard text [41]. A univariate ANOVA was carried out to establish any significant differences in the growth parameters of infected ZmRCP-1 and CaMV35S cell lines. Levene's test was used to establish homogeneity of variances.

\section{Authors' contributions}

SOO: Multiplication and molecular characterization of transgenic plants, GUS assays, nematode bioassays, data analysis and manuscript preparation; HR: Preparation of plasmid constructs, technical assistance, data analysis and manuscript preparation; JNT: Generation of transgenic plants and manuscript preparation; RC: Data collection; HJA: Supervision of research work, data analysis and manuscript preparation; ROO: Supervision of research work and manuscript preparation; LT: Research design, supervision of research work, data analysis and manuscript preparation. All authors read and approved the final manuscript.

\section{Author details}

${ }^{1}$ International Institute of Tropical Agriculture (IITA), P.O. Box 7878, Kampala, Uganda. ${ }^{2}$ Biotechnology and Biochemistry Department, Kenyatta University, P.O. Box 43844, Nairobi, Kenya. ${ }^{3}$ Centre for Plant Sciences, University of Leeds, Leeds LS2 9JT, UK.

\section{Acknowledgements}

The authors would like to thank Department for International Development (DFID) and Biotechnology and Biological Sciences Research Council (BBSRC) for their financial support, National Agricultural Research Laboratories (NARL) Uganda for providing research facilities. Assistance in data analysis from Dr. Nelson Owuor Onyango, a lecturer and a statistician from the University of Nairobi is highly appreciated.

\section{Competing interests}

The authors declare that they have no competing interests.

Received: 10 July 2015 Accepted: 8 March 2016

Published online: 29 March 2016

\section{References}

1. FAO Statistics. Food and Agriculture Organization of United Nations. Agriculture Data (FAO). 2012. http://www.Faostat.com.

2. Tripathi JN, Lorenzen J, Bahar O, Ronald P, Tripathi L. Transgenic expression of the rice Xa21 pattern-recognition receptor in banana (Musa sp.) confers resistance to Xanthomonas campestris pv. musacearum. Plant Biotech J. 2014;12:663-73.

3. Robinson JC. Bananas and plantains. Crop production science in horticulture 5. Wallingford: CABI Publishing; 1996.

4. Gowen S, Quénéhervé P. Nematode parasites of bananas, plantains and abaca. In: Luc M, Sikora RA, Bridge J, editors. Plant parasitic nematodes in subtropical and tropical agriculture. Wallingford: CABI Publishing; 1990. p. 431-60.

5. Atkinson HJ. Strategies for resistance to nematodes in Musa spp. In: Atkinson HJ, Dale J, Harding R, Kiggundu A, Kunert K, Muchwezi JM, et al., editors. Genetic transformation strategies to address the major constraints to banana and plantain production in Africa. Montpellier: INIBAP; 2003. p. 74-107.

6. Brentu CF, Speijer PR, Green KR, Hemeng BMS, De Waele D, Coyne D. Micro-plot evaluation of the yield reduction potential of Pratylenchus 
coffeae, Helicotylenchus multicinctus and Meloidogyne javanica on plantain cv. Apantu-pa (Musa spp., AAB-group) in Ghana. Nematology. 2004;6:455-62.

7. Ortiz R, Swennen R. From crossbreeding to biotechnology-facilitated improvement of banana and plantain. Biotechnol Adv. 2014;32:158-69.

8. Roderick H, Tripathi L, Babirye A, Wang D, Tripathi J, Urwin P, et al. Generation of transgenic plantain (Musa spp.) with resistance to plant pathogenic nematodes. Mol Plant Pathol. 2012;13:842-51.

9. Liu B, Hibbard JK, Urwin PE, Atkinson HJ. The production of synthetic chemodisruptive peptides in planta disrupts the establishment of cyst nematodes. Plant Biotechnol J. 2005:3:487-96.

10. Wang $D$, Jones LM, Urwin PE, Atkinson HJ. A synthetic peptide shows retro- and anterograde neuronal transport before disrupting the chemosensation of plant-pathogenic nematodes. PLoS One. 2011;6:e17475.

11. Green J, Wang D, Lilley CJ, Urwin PE, Atkinson HJ. Transgenic potatoes for potato cyst nematode control can replace pesticide use without impact on soil quality. PLoS One. 2012;7:e30973.

12. Tripathi L, Babirye A, Roderick H, Tripathi JN, Changa C, Urwin PE, et al. Field resistance of transgenic plantain to nematodes has potential for future African food security. Sci Rep. 2015;5:8127.

13. Lilley CJ, Wang D, Atkinson HJ, Urwin PE. Effective delivery of a nematode-repellent peptide using a root-cap-specific promoter. Plant Biotechnol J. 2011;9:151-61.

14. Santos Ordoñez EG. Characterization and isolation of T-DNA tagged banana promoters active during in vitro regeneration and low temperature stress. Leuven: Doctoral dissertation, Katholieke Universiteit Leuven; 2008. http://www.biw.kuleuven.be/dtp/tro/PhD-TRPL-pdf/PhD-EfrenSantos.pdf.

15. Tripathi L, Mwaka H, Tripathi JN, Tushemereirwe WK. Expression of sweet pepper Hrap gene in banana enhances resistance to Xanthomonas campestris pv. Musacearum. Mol Plant Pathol. 2010;11:721-31.

16. Tripathi JN, Muwonge A, Tripathi L. Efficient regeneration and transformation of plantain cv. "Gonja manjaya" (Musa spp. AAB) using embryogenic cell suspensions. In Vitro Cell Dev Biol Plant. 2012;48:216-24.

17. Matsuki $R$, Onodera $H$, Yamauchi T, Uchimiya $H$. Tissue-specific expression of the ro/C promoter of the Ri plasmid in transgenic rice plants. Mol Gen Genet. 1989;220:12-6.

18. Xu Y, Buchholz WG, De Rose RT, Hall TC. Characterization of a rice gene family encoding root-specific proteins. Plant Mol Biol. 1995;27:237-48.

19. Green J, Vain P, Fearnehough T, Worland B, Snape JW, Atkinson HJ. Analysis of the expression patterns of the Arabidopsis thaliana tubulin-1 and Zea mays ubiquitin-1 promoters in rice plants in association with nematode infection. Physiol Mol Plant P. 2002;60:197-205.

20. Koyama T, Ono T, Shimizu M, Jinbo T, Mizuno R, Tomita K, et al. Promoter of Arabidopsis thaliana phosphate transporter gene drives root-specific expression of transgene in rice. J Biosci Bioeng. 2005;99:38-42.

21. Goddijn OJ, Lindsey K, van der Lee FM, Klap JC, Sijmons PC. Differential gene expression in nematode-induced feeding structures of transgenic plants harbouring promoter-gusA fusion constructs. Plant J. 1993:4:863-73.

22. Urwin PE, Møller SG, Lilley CJ, McPherson MJ, Atkinson HJ. Continual green-fluorescent protein monitoring of cauliflower mosaic virus $35 \mathrm{~S}$ promoter activity in nematode-induced feeding cells in Arabidopsis thaliana. Mol Plant Microbe Interact. 1997;10:394-400.

23. Møller SG, Urwin PE, Atkinson HJ, McPherson MJ. Nematode-induced expression of atao1, a gene encoding an extracellular diamine oxidase associated with developing vascular tissue. Physiol Mol Plant P. 1998;53:73-9.
24. Matsuyama T, Yasumura N, Funakoshi M, Yamada Y, Hashimoto T. Maize genes specifically expressed in the outermost cells of root cap. Plant Cell Physiol. 1999;40:469-76.

25. Tripathi L, Tripathi JN, Kiggundu A, Korie S, Shotkoski F, Tushemereirwe WK. Field trial of Xanthomonas wilt disease-resistant bananas in East Africa. Nat Biotechnol. 2014;32:868-70.

26. Maldonado A, Youssef R, McDonald M, Brewer E, Beard H, Matthews B. Overexpression of four Arabidopsis thaliana NHL genes in soybean (Glycine max) roots and their effect on resistance to the soybean cyst nematode (Heterodera glycines). Physiol Mol Plant Path. 2014;86:1-10.

27. Ghag SB, Shekhawat UKS, Ganapathi TR. Host-induced post-transcriptional hairpin RNA-mediated gene silencing of vital fungal genes confers efficient resistance against Fusarium wilt in banana. Plant Biotech J. 2014;12:541-53.

28. Wuyts N, Maung ZTZ, Swennen R, De Waele D. Banana rhizodeposition: characterization of root border cell production and effects on chemotaxis and motility of the parasitic nematode Radopholus similis. Plant Soil. 2006;283:217-28.

29. Hawes MC, Bengough G, Casab G, Ponce G. Root caps and rhizosphere. J Plant Growth Regul. 2003;21:352-67.

30. Wyss U, Grundler FMW, Münch A. The parasitic behaviour of second stage juveniles of Meloidogyne incognita in roots of Arabidopsis thaliana. Nematologica. 1992;38:98-111.

31. Sarah JL, Pinochet J, Stanton J. The burrowing nematode of bananas Radopholus similis Cobb 1913. Musa Pest Fact Sheet No. 1. Montpellier: INIBAP; 1996.

32. Brooks FE. Burrowing nematode. The Plant Health Instructor. 2008. doi: 10.1094/PHI-I 2008-1020-01.

33. Zimmermann P, Zardi G, Lehmann M, Zeder C, Amrhein N, Frossard E, et al. Engineering the root-soil interface via targeted expression of a synthetic phytase gene in trichoblasts. Plant Biotechnol J. 2003;1:353-60.

34. Chen P-Y, Wang C-K, Soong S-C, To K-Y. Complete sequence of the binary vector pBl121 and its application in cloning T-DNA insertion from transgenic plants. Mol Breeding. 2003;11:287-93.

35. Sambrook J, Russell DW. Molecular cloning: a laboratory manual. 3rd ed. New York: Cold Spring Harbor Laboratory Press; 2001.

36. Hood EE, Gelvin SB, Melchers LS, Hoekema A. New Agrobacterium helper plasmid for gene transfer to plants. Transgenic Res. 1993;2:208-18.

37. Murashige T, Skoog F. A revised medium for rapid growth and bio assays with tobacco tissue cultures. Physiol Plant. 1962;15:473-97.

38. Jefferson RA. Assaying chimeric genes in plants: the GUS fusion system. Plant Mol Biol Rep. 1987;5:387-405.

39. Nyombi K, Van Asten PJA, Leffelaar PA, Corbeels M, Kaizzi CK, Giller KE. Allometric growth relationships of East Africa highland bananas (Musa AAA-EAHB) Cv. Kisansa and Mbwazirume. Ann Appl Biol. 2009;155:403-18.

40. Southey J. Laboratory methods for work with plant and soil nematodes. London: Her Majesty's Stationery Office; 1986 (Reference Book 402).

41. Snedecor GW, Cochran WG. Statistical methods. 8th ed. Ames: Iowa State University Press; 1989

\section{Submit your next manuscript to BioMed Central and we will help you at every step:}

- We accept pre-submission inquiries

- Our selector tool helps you to find the most relevant journal

- We provide round the clock customer support

- Convenient online submission

- Thorough peer review

- Inclusion in PubMed and all major indexing services

- Maximum visibility for your research

Submit your manuscript at www.biomedcentral.com/submit
() Biomed Central 